\title{
Sanat Yapıtlarından Alıntılamanın Resim Anasanat Atölye Öğrencilerinin Çalışmalarına Etkisi
}

(1) Öğr. Gör. Dr. Leyla Kodaman

(2) Doç. Dr. Meliha Yılmaz

\section{Öz}

Bu çalışma, sanat eğitimi alan öğrencilerin, geçmişten günümüze dek uzanan büyük sanat yapıtlarının ve sanatçıarııı yol gösterici eserleri ile yapıldığı dönemleri ve sanatçılarını tanıyarak, onlardan beslenerek özgün eserler üretebilmenin ilk basamaklarından biri olacağı düşünülerek gerçekleştirilmiştir. Ayrıca çalışmayla Resim Anasanat atölye öğrencilerine, resim çalışmaları kapsamında eleştiri yapabilme, farkıı bakış açılarıyla özgün düşünme ve üretebilme becerilerinin kazandırılması amaçlanmışıır.

"Sanat yapıtlarından alıntılamanın Resim Anasanat atölye öğrencilerinin çalısmalarına etkisi" konulu araştırma kapsamında, deney ve kontrol grubuna uygulanmak üzere konuları peyzaj ve figürlü kompozisyon olarak belirlenmiş, öntest - sontest ve kalıclık testleri yapılmıştı. Bu testler sonucunda deney ve kontrol grubu öğrencilerinin başarıları arasında fark olup olmadığı SPSS programılla yapılan bağımsız t-testi analizleriyle ortaya konulmuştur.

Anahtar Kelimeler: Sanat, Alıntılama, Sanat Yapıtı

THE EFFECT OF ADAPTATION OF ARTWORKS TO THE WORK OF STUDENTS OF MAIN PAINTING ART WORKSHOP

\begin{abstract}
This study is expected to be one of the first steps for the art students to produce unique art works by knowing the great artists from past to present, their art works, their periods, adapting their guidance and studies. In addition, it has been forgotten that adapting from art works, which is one of the teaching methods, during the education process contributes to the process.

The pre-test, post-test and retention tests, with the subjects of landscape and figurative compositions, were applied to the control and experimental groups within the scope of the study, with a topic of "The contribution of adapting from art works the to the work of the painting arts studio students", in order to find answers to the problems included in the study. As a result of these tests, the difference between the achievements of the groups has been presented by analyses of independent-test with SPSS software.
\end{abstract}

Keywords: Art, Adaptation, Work of Arts

(1) Süleyman Demirel Üniversitesi Güzel Sanatlar Fakültesi, Resim Bölümü, ISPARTA, e-posta: leylakodaman@sdu.edu.tr

(2) Gazi Üniversitesi Eğitim Fakültesi, Güzel Sanatlar Eğitimi, Resim- İş Öğretmenliği

Bölümü, ANKARA, e-posta: mel.yilmaz0637@gmail.com 


\section{Giriş}

Araştırma, sanat yapıtlarından alıntılama yönteminin Resim Anasanat atölye öğrencilerinin çalışmalarına etkisinin olup olmadığının, var ise hangi düzeyde olduğunun belirlenmesi amacıyla yapılmıştır. GSF Resim Anasanat atölye öğrencilerinin uygulamalı çalışmalara başlarken "Nasıl resim yapacağım? Hangi temaları işleyeceğim? Verilen konuları nasıl resme dönüştürüp kurgulayacağım? Nasıl kompozisyonlar üreteceğim?" gibi çoğaltabileceğimiz sorularına cevap aramak için yapılan araştırma ile ünlü sanat yapıtlarından alıntılamanın sanat eğitimi alan öğrencilere bir çıkış noktası olacağı düşünülmektedir. Bu araştırmayla Güzel Sanatlar Fakültesi Resim Bölümlerinde, Resim Anasanat atölye dersi öğrencilerine, resim çalışmaları kapsamında eleştiri yapabilme, farklı bakış açılarıyla özgün düşünme ve üretebilme becerilerinin kazandırıması amaçlanmaktadır. Sanat hayatı boyunca alıntılama yöntemini sıkça kullanmış başta Picasso olmak üzere birçok sanatçı ve eserleri incelenerek, resimlerinde alıntılamayı ne şekilde kullandıkları öğrenciler tarafından örnek alınarak atölye çalışmalarına önemli bir ivme kazandırması amaçlanmıştır (Bkz.Res:1-2-3-4).
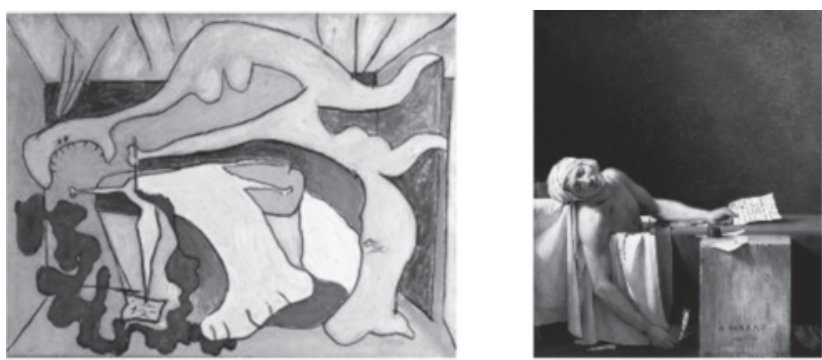

Resim 1: Picasso, Marat'ın Ölümü, 1931, tuvale yağlıboya, 116×150 cm Resim 2: Jacques-Louis David, Marat'ın Ölümü, 1793, 165×128 cm
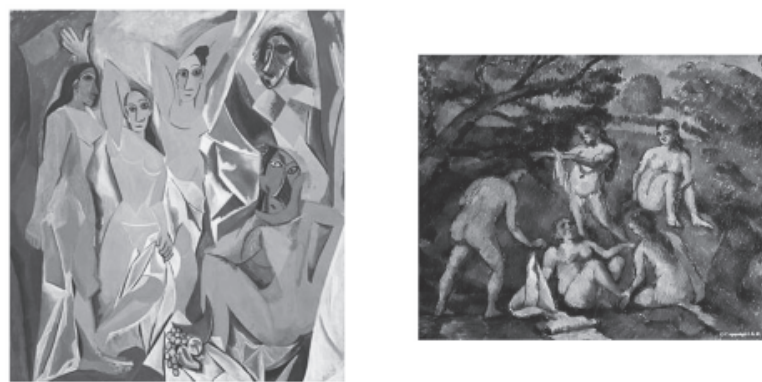

Resim 3: Pablo Picasso, Avignonlu Kızlar, 1907, tuvale yağlıboya, 244×234 cm Resim 4: Paul Cezanne, Beş Yıkanan,1886, tuvale yağlıboya 40.6x42.9 cm 
Bunun yanı sıra sanat eserlerinden alıntı yapmak suretiyle farklı kompozisyonlar üretebilme becerisi ve yaratıcılıklarını geliştirecek farklı deneyimler kazanabilme imkânı sağlama açısından da sanat yapıtlarından alıntılama yönteminin önemli olacağı düşünülmektedir. Sanat yapıtları, yeniden canlandırılabilmelerinden dolayı, kuramsal olarak, herkesçe kullanılmıştır. Hemen hemen her dönemde alıntılamaya başvuran ve hayranlık duydukları birçok sanatçının eserlerinden yararlanarak benzerini yapan çok sanatçı vardır (Berger, 1990: 29). J.Coignard "Bir tablo veya heykele bakmak ve konturlarını çizmek için, acemice de olsa atılan birkaç çizgi bazen büyük bir söylev ya da fotoğraftan fazla şey öğretir. Tabii ki bu harika eserler kitabını zamanında kapatmasını bilmek gerekir" diyerek ileri boyutta büyük sanatçılarla haşır neşir olmanın tehlikeli olabileceğini de belirtmiştir. Ama bunun yanı sıra; Bacon veya Manet'nin Velazquez'siz, Picasso'nun Ingres'siz, Degas'nın Mantegna'sız, Delacroix'nın Rubens ve Veronese'siz, Ingres'in antik çağsız, Rubens'in Venediksiz, Roma'nın da Yunansız yapamadığını söylemiştir (1995: 33). Yılmaz'a göre (2010: 248) sanat eğitimi alan öğrencilere sanat eserlerini tanıma, anlama, teknik beceri kazandırma ve görsel birikim sağlayarak imge zenginleştirme amacıyla, nitelikli sanat yapıtlarından eser eleştirisi, eser yorumlama, bellek eğitimi gibi çalışmalar yaptırılmalıdır, fakat mümkün olduğunca birebir kopya çalışmalarından uzak durmaları sağlanmalıdır. Bu doğrultuda sanat yapıtlarından alıntılama yöntemi ile öğrencilerin birebir kopyaya yönelimi engellenebilir.

\section{Sanat ve Sanat Yapitı}

"Sanat Nedir?" sorusuna Picasso tarafından " Sanat ne değildir ki" şeklinde verilen ve çok yoğun bir anlam taşıyan bu yanıttan sonra söylenecek pek fazla bir şey yok gibi gözükmektedir. Fakat aynı Picasso, başka bir zaman aynı soruya "bilseydim onu kendime saklardım" diye de yanıt verebilmektedir (Erinç, 1993: 3).

Sanat denilen bir şeyin olmadığını söyleyen Gombrich ise sadece sanatçılar vardır (2007: 15) diyerek, sanatın sanatçıyla var olduğunu vurgulamaktadır. Yazar, bir zamanlar mağara duvarlarına resim çizen, bugünse boya satın alıp reklam afişleri yapan ve yüzyıllardan beri daha birçok şeyler üreten insanların yaptığı tüm etkinliklerin de sanat olarak tanımlanmasında bir sakınca görmez.

Sıtkı M. Erinç; "Sanatı, var olmanın ön koşullarından biri olarak görür. Böyle kabul edildiğinde onun sayısız boyutlarının, yaşamın her 
alanına girdiğini ve o alanları yeniden yaratmak durumunda da kaldığını söyler" (2004: 7).

Sanat nedir? Sorusuna Toltsoy, şu açıklamaları getirmektedir:

"Şunu unutmamalıdır ki, sanat bir fedakârlık abidesidir. Eğer siz fedakârlığa talip değilseniz, milyonlarca insanın ömrünü verdiği bu müesseseye katılmaya hakkınız yok" (1996: 70).

Sanatın neredeyse insanla yaşıt olduğunu söyleyen Fischer, onun bir çeşit çalışma olduğunu, çalışmanın da insana özgü olduğunu belirterek sanatın geçmişte olduğu gibi gelecekte de gerekli ve var olacağını dile getirir (2012: 21-22).

Sanat gerçekten karmaşık bir kavramdır. Heykel ve resim gibi güzel sanatlar veya diğer görsel sanatlar, tiyatro, opera ve dans gibi gösteri sanatları ve müzik, şiir ve roman gibi dil sanatları (edebiyat) ve filmleri içermektedir (Bendixen, 2010: 12).

Açıkçası sanatın ne olduğu, nasıl tanımlandığı konusunda sayısız tanım ve söylem olduğunu söyleyebiliriz. Son olarak sanatı, kimsenin düşünemediğini düşünmek, kimsenin göremediğini görüp göstermek, üretmek ve sunmaktır, diye de ifade edebiliriz.

Sanat, sanatçının duygu ve yaşantısı, hayal gücünün özgür bir yaratımının ifadesidir. Croce ve Hegel sanatı yaratmanın özünde bulurlar. Estetik yaşantı özerk bir alandır, buna göre sanat yapıtı da kendine özgü nitelikleri olan ve bu nitelikler aracılığıyla kavranabilecek bir gerçekliktir (Ötgün, 2009: 162).

Lenoir "Sanat yapıtlarının bize hem aşina, hem de yabancı olduğunu söyleyerek" (2004: 7) bu durumu şöyle açılar: çünkü onlara her yerde rastlarız. Biçim olarak roman ya da film, röprodüksiyon ya da anıt olarak, bunların dışında da yaratıcısının yeteneği sayesinde sanat yapıtı katına yükselmiş, her gün kullandığımız eşyalardan biri olarak, farklı adlarla bizim günlük yaşamımızın birer parçası haline gelmişlerdir.

Büyükdüvenci (2006: 47) ise sanat yapıtını kısaca şöyle tanımlamaktadır; Tüm estetik sistemler, özel türden bir duygu, heyecanla ilgili kişisel özel deneyimi çıkış noktası olarak alır. Böylesi bir duyguyu harekete geçiren nesneler, sanat yapıtıdır.

Insanların sanat anlayışları temelde insan ve insanlık anlayışına bağlanmış ve bunun göstergelerini de iki yolla belirtmişlerdir. Birincisi; Eğer bir yapıt insanda "estetik haz" uyandırıyorsa o bir sanat eseridir, ikincisi de; Eğer bir yapıt bir mesaj veriyorsa o sanat eseridir. Bir toplum yapıta ne zaman böyle bir işlev yüklerse, bunlardan birini veya her ikisini yüklerse o zaman yapıt sanat eseri sayılır (Erinç, 2009: 53).

Öyleyse bir sanat yapıtı insanda güzel duygular uyandıran ve 
izleyenle arasında bir bağ oluşturan estetik bir objedir.

\section{Alıntılama Nedir? Sanat Yapıtlarından Alıntılama}

Alıntılama, "ünlü sanat yapıtlarının çeşitli bölümleri kopya edilerek, bütünlük kaygısı güdülmeden bir araya getirilmesiyle oluşturulan eklektik (seçmeci) yapıt" olarak tanımlanmaktadır (Eczacıbaşı Sanat Ansiklopedisi, 1997: 1435). Ayrıca bir sanatçının üslubu taklit edilerek gerçekleştirilen yapıta da bu ad verilir" şeklinde de tanımlanmaktadır. Alıntılama, post-modern metinlerin iç bünyesinde karşımıza çıkan bir ifade ve anlatım öğesidir. Klasizmden başlayarak modern edebiyatın yaygınlık kazanmaya başlaması ve onu takip eden romantizm, realizm, natüralizm gibi akımlarla pekişerek yeni ifade biçimleri oluşturmaları, modern edebi eserlerin kendi doğalarına uygun üslup ve anlatım biçimlerinin doğmasını sağlamıştır.

Rosenau'a göre alıntılama; "fikirlerin ya da görüşlerin gelişi güzel, darmadağınık, kolajı andııı biçimde bir araya gelerek oluşturdukları kırkyamadır (patchwork). Alıntılama eski-yeni gibi karşıt unsurları bünyesinde barındırır. Düzenliliği, mantığı ya da simetriyi yadsır; çelişki ve karşıtlıktan hoşlanır" (Emre, 2006: 156).

Aktulum ise, (2011a: 337) alıntılamayı; bir çalı̧̧ma yöntemi ve resim tekniği olarak pek çok ressamca uygulanmış, diğerinin yapıtından şu veya bu şekilde alıntılama yaparak, zamansal ve uzamsal göndermeler yapan bir dizge ve izleyici ile izlenen nesneyi karşı karşıya getirerek sorgulayan bir işlem olarak tanımlar.

Alıntılama; ünlü sanat yapıtlarının farklı bir bakış açısıyla yeniden ele alınıp günümüze taşınması, aktarıması, sanatçının kendi özgün duygu yoğunluğu ile yaşadığı dönemde yeniden canlandırılması ve yorumlanmasıdır. Kısaca alıntılama, geçmişten günümüze özgün bir dille yeniden kurgulama, aktarıldığı yeni dönemin diliyle anlam kazanma ve ifade edilmesidir.

Alıntılama biçimleri sanatçıdan sanatçıya çeşitlilik gösterebilmektedir. Bir yapıt başka bir yapıta ilişkin motifi, bir izleği yalın bir biçimde alıntılayabilir. Diğer bir yapıttan biçemsel bir alıntıda yapabilir. Kısaca bir sanatçının resmetme biçimi de taklit edilebilir, başka bir ressamın yapıtı yeni bir yapıtta olduğu gibi yinelenebilir. Birçok sanatçı benzer bir yol izleyerek alıntının değişik biçimlerine başvurur ve sanat tarihinden olduğu kadar çevrelerindeki kültürden de beslenebilirler (Aktulum (b), 2011: 59).

Sanat yapıtlarından alıntılamanın Resim Anasanat atölye derslerine 
etkilerinin araştırıldığı bu çalışmada nicel yöntemler kullanılmıştır. Nicel verilerde anahtar kavram niceliktir ve niceliği açıklamak için sayılar kullanılır. Bu nedenden ötürü nicel veriler sayısal sonuçlar veren ve sayılarla açılanan bir dünya bilgisidir (Punch, 2005: 57). Araştırmada " gerçek deneme modelleri, öntest - sontest kontrol gruplu model olan deneysel desen" modelinden yararlanılmıştır. Bu yöntemin seçilmesinin temel nedeni, herhangi bir "Şeyin" (yeni bir öğrenme yöntemi, yeni bir program, yeni bir sınıf düzeni vb) etkililiğini ölçmek ve çıkan sonuç olumlu ise, bundan yararlanılarak önerilerde bulunmaktır (Ekiz, 2003: 99).

Bilimsel değeri en yüksek denemeler, gerçek deneme modelleriyle yapılandır. Gerçek deneme modellerinin ortak özellikleri, birden çok grup kullanılması ve grupların yansız atama (örnekleme) ile oluşturulmasıdır. Böylece, her araştırmada en az bir deney bir de kontrol grubu bulunur. Bunlar, öteki kontrol değişkenleri açısından "eşitlenmiş" sayılır (Karasar, 2005: 95).

Deneysel model araştırmacının kontrolü altında değişkenler arasındaki neden-sonuç ilişkilerini keşfetmek için gözlenmek istenen verilerin üretildiği araştırma alanıdır (Büyüköztürk, 2001: 27).

Araştırmanın evrenini, Akdeniz Bölgesinde bulunan Antalya ve Isparta illeri, çalışma grubunu ise Isparta il merkezinde bulunan Süleyman Demirel Üniversitesi ve Antalya il merkezinde bulunan Akdeniz Üniversitesi Güzel Sanatlar Fakülteleri Resim Bölümünde eğitim gören 3. sınıf öğrencileri oluşturmaktadır. Araştırma Isparta İlinde bulunan SDÜ GSF Resim Bölümü 3. sınıf öğrencilerinden oluşturulan 15 Deney Grubu ve Antalya ilinde bulunan AÜ GSF Resim Bölümü 3. Sınıf öğrencilerinden oluşturulan 15 Kontrol Grubu ile toplamda otuz (30) öğrenci ile yapılmıştır.

Araştırmanın veri toplama araçları, deney ve kontrol grubu öğrencilerinin öntest- sontest ve kalıcılık testi kapsamında oluşturdukları resimler ve bu resimlerin puanlanması sonucunda elde edilen puanlama tablolarıdır.

Çalışmada öntest, sontest ve öğrenilenlerin kalıcı olma düzeyini belirlemeye yönelik kalıcılık testinden elde edilen veriler ayrı ayrı kodlanarak bilgisayar ortamına aktarılmıştır. Verilerin analizinde SPSS programılla, istatistikî işlemlerden (independent sample t-test) t- testi, aritmetik ortalama $(X)$, standart sapma (s) kullanılmıştır. Elde edilen verilerin anlamlı olup olmadıkları 0.05 manidarlık düzeyinde test edilmiştir. Ayrıca öntest - sontest ve kalıcılık testi sonunda elde edilen uygulamalı çalışmaları, belirlenen kriterler doğrultusunda 1 ile 5 arasında 
puanlayan uzmanlar arasındaki tutarlılık, Kappa Testiyle (Hakemler arası tutarlılık) tablo 1'de görüldüğü üzere ortaya koyulmuştur. Sonuçlara göre; uzmanlar arasındaki tutarlılığın makul düzeyde ve geçerli olduğu tespit edilmiştir.

\begin{tabular}{lcccc}
\hline & Kappa Değeri & Standart Hata & T Değeri & $\begin{array}{c}\text { p-değeri } \\
\text { (Anlamlılık) }\end{array}$ \\
\hline 1.UZMAN- 2.UZMAN & 0,219 & 0,075 & 9,140 & $* * * *$ \\
1.UZMAN- 3.UZMAN & 0,219 & 0,075 & 9,140 & $* * *$ \\
2.UZMAN- 3.UZMAN & 0,247 & 0,080 & 8,325 & $* * *$ \\
\hline
\end{tabular}

*** $p \leq 0.001$ seviyesinde önemli. ${ }^{* *} p \leq 0.01$ seviyesinde önemli. ${ }^{*} p \leq 0.05$ seviyesinde önemli Tablo 1: Hakemler Arası Tutarlılık (Kappa) Testi

Deney ve kontrol grubu öğrencilerine uygulamaya başlamadan önce araştırma konusu ile ilgili herhangi bir eğitim verilmemiştir. Öğrencilere sadece yapacakları uygulamalı çalışmaların konusu olarak belirlenen peyzaj ve figürlü kompozisyonla ilgili bilgi verilmiş ve örnekler gösterilmiştir. Deney ve kontrol grubu öğrencileriyle yapılan öntest kapsamında öğrenciler, konuları peyzaj ve figürlü kompozisyon olarak belirlenen iki yağlı boya resim yapmıştır. Her iki grup öntest uygulama aşamasında dört hafta boyunca geleneksel yöntemler doğrultusunda çalışmalarını gerçekleştirmiştir. Bir sonraki aşama olan sontest kapsamında deney grubu öğrencilerine araştırmamızın ana konusu olan sanat yapıtlarından alıntılama yöntemi anlatılmış, bu yöntemi sıkça kullanmış olan başta Picasso ve birçok sanatçı (E. Manet, J.D.Ingres, H. Matisse, B. Vega vb.) eserleriyle birlikte örnek olarak gösterilmiş ve incelenmiştir. Bu sanatçıların alıntılama şekli örnek alınarak deney grubu öğrencileri kendi seçtikleri sanatçı ve eserlerinden alıntılama yaparak dört hafta boyunca sontest çalışmalarını oluşturmuşlardır. Kontrol grubuna ise yine araştırma konusu ile ilgili bilgi verilmemiş, geleneksel yöntemlerle çalışmalarına devam etmeleri söylenmiştir. Sontest uygulamalarının tamamlanmasından sonra her iki gruba da bir ay sonra kalıcılık testi yapılmıştır. Böylece puanlaması yapılacak veriler elde edilmiştir. Çalışmalar alan uzmanı üç öğretim üyesi tarafından, kompozisyonda özgünlük ve hayal gücünü kullanma, renk kullanımı, biçim zenginliği ve ayrıntılara ilgi, biçim özgünlüğü, hareket ve ritim, çalışmanın konuya uygunluğu çalışmanın tamamlanması bakımından 1 ile 5 arasında puanlanmıştır. Elde edilen veriler doğrultusunda ve verilen eğitim sonrasında öntest, sontest ve kalıcılık testleri açısından deney ve kontrol grubu arasında fark olup olmadığı aşağıdaki alt amaçlar doğrultusunda test edilmiştir. 
$\mathrm{Bu}$ uygulamalar sonucunda deney ve kontrol grubunun t-testi analiz sonuçları ve araştırmanın alt amaçlarına dayalı bulgu ve yorumlar şöyledir;

\begin{tabular}{|c|c|c|c|c|c|c|}
\hline Test & Grup & Ortalama & Gözlem Sayısı & Standart Sapma & t-testi & $\begin{array}{c}\text { p-değeri } \\
\text { (Anlamlılık) }\end{array}$ \\
\hline \multirow{2}{*}{ Öntest } & Deney* & 25,6600 & 15 & 5,12265 & \multirow{2}{*}{1,658} & \multirow{2}{*}{0,116} \\
\hline & Kontrol ${ }^{* * *}$ & 23,3500 & 15 & 1,69421 & & \\
\hline
\end{tabular}

1- Sanat yapıtlarından alıntılamanın Resim Anasanat atölye öğrencilerinin çalışmalarına etkisine yönelik uygulama öncesinde deney ve kontrol grubunun öntest puanları arasında anlamlı bir farklılık olup olmadığına yönelik bulgular.

Tablo 2'de görüldüğü üzere öntest başarı puanları t-testi analiz sonuçları deney grubunun ortalama değeri 25,66, kontrol grubunun ortalama değeri ise 23,35 olup iki grup arasında 2,31 puanlık bir fark bulunmaktadır. Gruplar arasında istatistiksel olarak bir fark olup olmadığına yönelik alt amaca ilişkin t-değeri 1,658 olarak hesaplanmıştır. Elde edilen farkın istatistiksel olarak anlamlı olmadığı sonucuna ulaşılmıştır [ $t(28)=1,658 \quad p>0,05 \quad]$. Öntest açısından değerlendirildiğinde deney ve kontrol grubu puanları arasında istatistiksel olarak anlamlı bir fark bulunmamaktadır. Başka bir anlatımla; grupların denk olduğu söylenebilir. Öntest sonrasında her iki grubun oluşturduğu uygulamalara bakıldığında, kompozisyonlarda özgünlük ve hayal gücünü kullanma, renk kullanımı, biçim özgünlüğü, çalışmanın konuya uygunluğu, hareket ve ritim, çalışmanın tamamlanması açısından birbirine denk olduğu söylenebilir.

\begin{tabular}{llccccc}
\hline Test & Grup & Ortalama & Gözlem Sayıs1 & Standart Sapma & t-testi & $\begin{array}{c}\text { p-değeri } \\
\text { (Anlamllik) }\end{array}$ \\
\hline \multirow{2}{*}{ Sontest } & Deney & 33,4633 & 15 &, 69989 & 10,170 & \multirow{2}{*}{000} \\
& Kontrol & 25,0700 & 15 &, 43730 & & \\
\hline
\end{tabular}

Tablo 3: Deney ve Kontrol Grubu Sontest Başarı Puanları t-testi Analiz Sonuçları

2- Sanat yapıtlarından alıntılamanın Resim Anasanat atölye öğrencilerinin çalışmalarına etkisine yönelik uygulama sonrasında deney ve kontrol grubunun sontest puanları arasında anlamlı bir farklılık olup olmadığına yönelik bulgular. 
Öntest sonuçlarına göre farklılık göstermeyen deney ve kontrol grubu arasında, sontest sonrası farklılık olup olmadığı 4 hafta süren Resim Anasanat atölye çalışmaları kapsamında yapılan sontest ile ortaya konulmuştur. Araştırma konusuyla ilgili bilgi aktarımının yapılmadığı kontrol grubu ile bilgi aktarımının yapıldığı deney grubu arasındaki sontest analiz sonuçları şöyledir; (Bkz. Tablo 3).

Sontest açısından deney grubu değerlendirme puanı 33,4633, kontrol grubu değerlendirme puanı ise 25,0700 'dür. İki grup arasındaki fark 8,3933' tür. İki grup arasındaki farka ilişkin t değeri 10,17 olup istatistiksel olarak anlamlıdır [ $t(28)=10,17 \mathrm{p} \leq 0,05$ ]. Başka bir anlatımla; sontest açııından deney grubu öğrencilerinin ortalama başarısı kontrol grubu öğrencilerine göre daha yüksek olup bu fark istatistiksel olarak da anlamlıdır. 4 hafta süren sontest uygulamasının sonucunda sanat yapıtlarından alıntılamanın Resim Anasanat atölye çalışmalarına etkisi konulu araştırmada deney grubu öğrencileri lehine anlamlı bir fark görülmüştür.

Sontest sonrasında her iki grubun oluşturduğu uygulamalara bakıldığında, kompozisyonlarda özgünlük ve hayal gücünü kullanma, renk kullanımı, biçim özgünlüğü, çalışmanın konuya uygunluğu, hareket ve ritim, çalışmanın tamamlanması açısından, deney grubunun daha başarılı olduğu ve sanat yapıtlarından alıntılama yöntemiyle oluşturdukları çalışmalarda daha özgün, daha cesur ve daha yaratıcı oldukları tespit edilmiştir. Kontrol grubu öğrencilerinin sontest sonrasında ortaya çıkan kompozisyonlarında ise; özgünlük ve hayal gücünü kullanma, renk kullanımı, biçim özgünlüğü, çalışmanın konuya uygunluğu, hareket ve ritim, çalışmanın tamamlanması bakımından hemen hemen benzer, kararsız, özgün olmayan, kalıplaşmış işlerin ortaya çıktığı görülmüştür.

\begin{tabular}{llccccc}
\hline Test & Grup & Ortalama & Gözlem Sayısı & Standart Sapma & t-testi & $\begin{array}{c}\text { p-değeri } \\
\text { (Anlamlılk) }\end{array}$ \\
\hline \multirow{2}{*}{ Kalıcılı testi } & Deney & 33,18 & 15 & 3,172 & 6,637 &, 000 \\
& Kontrol & 27,32 & 15 & 1,266 & \\
\hline
\end{tabular}

Tablo 4: Deney ve Kontrol Grubu Kalıcılık Testi Başarı Puanları t-testi Analiz Sonuçları

3- Sanat yapıtlarından alıntılamanın Resim Anasanat atölye öğrencilerinin çalışmalarına etkisine yönelik uygulama sonrasında deney ve kontrol grubunun kalıcılık testi puanları arasında anlamlı bir farklıık olup olmadığına yönelik bulgular.

Benzer şekilde kalıcılık testi açısından sonuçlara baktığımızda iki grup arasındaki farklıı̆ga ilişkin t -değeri 6,637 olarak hesaplanmış olup; bu sonuç, istatistiksel olarak deney grubu ortalama puanının kontrol 
grubundan daha yüksek olduğunu göstermektedir [ $\mathrm{t}(28)=6,637 \mathrm{p} \leq$ 0,05 ] (Bkz. Tablo 4). Kalıcılık testi sonrasında her iki grubun oluşturduğu uygulamalara bakıldığında, kompozisyonlarda özgünlük ve hayal gücünü kullanma, renk kullanımı, biçim özgünlüğü, çalışmanın konuya uygunluğu, hareket ve ritim, çalışmanın tamamlanması bakımından, yine deney grubunun daha başarılı olduğu saptanmıştır. Deney grubunun sanat yapıtlarından alıntılama yöntemiyle oluşturduğu çalışmalarda, daha özgün ve yaratıcı işler ortaya çıkarması, yöntemin kalıcı olduğunu da göstermiştir. Kontrol grubu öğrencilerinin çalışmalarına bakıldığında ise, öntest ve sontest sonrasında ortaya çıkan kompozisyonlarda; özgünlük ve hayal gücünü kullanma, renk kullanımı, biçim özgünlüğü, çalışmanın konuya uygunluğu, hareket ve ritim, çalışmanın tamamlanması bakımından hemen hemen benzer, kararsız, özgün olmayan, kalıplaşmış işlerin ortaya çıktığı görülmüştür. Fakat aynı konular üzerinde tekrar tekrar çalışmanın kompozisyonlara teknik anlamda azda olsa katkı sağladığı söylenebilir.

\begin{tabular}{|c|c|c|c|c|c|c|}
\hline Grup & Uygulama & $\begin{array}{c}\text { Gözlem } \\
\text { Sayısı }\end{array}$ & Ortalama & $\begin{array}{l}\text { Standart } \\
\text { Sapma }\end{array}$ & t-testi & $\begin{array}{c}\text { p-değeri } \\
\text { (Anlamlılık) }\end{array}$ \\
\hline \multirow{3}{*}{ Deney } & Öntest & \multirow{2}{*}{15} & 25,6600 & 5,12265 & \multirow{2}{*}{$-5,215$} & \multirow{2}{*}{, 000} \\
\hline & Sontest & & 33,4633 & 2,71066 & & \\
\hline & $\begin{array}{l}\text { Öntest } \\
\text { Kalıcılık testi }\end{array}$ & 15 & $\begin{array}{l}25,6600 \\
33,1767\end{array}$ & $\begin{array}{l}5,12265 \\
3,17242\end{array}$ & $-4,832$ &, 000 \\
\hline
\end{tabular}

Tablo 5: Deney Grubu Öntest - Sontest ve Öntest- Kalıcılık Testi Başarı Puanları, t-testi Analiz Sonuçları

4- Sanat yapıtlarından alıntılamanın Resim Anasanat atölye öğrencilerinin çalışmalarına etkisine yönelik uygulama sonrasında deney grubunun öntest-sontest puanları arasında anlamlı bir farklılık olup olmadığına yönelik bulgular.

Tablo 5 'te görüldüğü üzere deney grubu öntest - sontest puanlama değeri sırasıyla 25,66 ve 33,46 olup, öntest - sontest arasındaki farka ilişkin t-değeri -5,215 olarak hesaplanmıştır. Elde edilen değere göre deney grubu ön test ve son test puanları arasında istatistiksel olarak anlamlı bir fark vardır [ $t(28)=-5,215 p \leq 0,05$ ]. Başka bir anlatımla; uygulama sonrasında deney grubu öğrencilerinin başarıları anlamlı bir şekilde artmıştır. Deney grubu öğrencilerinin sontest başarı puanlarındaki anlamlı artış, sanat yapıtlarından alıntılamanın Resim Anasanat atölye öğrencilerinin çalışmalarına etkisine yönelik uygulamanın öğrencilerin atölye çalışmalarına önemli katkılar sağladığını göstermektedir. Öntest - sontest sonrasında deney grubunun oluşturduğu uygulamalara bakıldığında, kompozisyonlarda özgünlük ve hayal gücünü kullanma, renk kullanımı, biçim özgünlüğü, çalışmanın 
konuya uygunluğu, hareket ve ritim, çalışmanın tamamlanması açısından, deney grubunun başarısının önemli ölçüde arttığı saptanmıştır. Deney grubunun sanat yapıtlarından alıntılama yöntemiyle oluşturduğu sontest çalışmalarının, öntest sonrası çalışmalarından daha özgün ve yaratıcı olduğu tespit edilmiştir.

5- Sanat yapıtlarından alıntılamanın Resim Anasanat atölye öğrencilerinin çalışmalarına etkisine yönelik uygulama sonrasında deney grubunun öntest-kalıcılık testi puanları arasında anlamlı bir farklılık olup olmadığına yönelik bulgular.

Tablo 5 'te görüldüğü üzere deney grubu öğrencilerinin öntest ve kalıcılık testi puanlama değeri sırasıyla 25,66 ve 33,17 olup, aradaki farka ilişkin t-değeri $-4,832$ olarak hesaplanmıştır. Elde edilen değere göre deney grubu öntest ve kalıcılık testi puanları arasında istatistiksel olarak anlamlı bir fark vardır [ $t(28)=-4,832 p \leq 0,05$ ]. (Bkz. Tablo 6).

Başka bir anlatımla; deney grubu öğrencilerinin kalıılık testi sonrası puanlarındaki anlamlı artışla, sanat yapıtlarından alıntılamanın Resim Anasanat atölye öğrencilerinin çalışmalarına etkisine yönelik uygulamanın, öğrencilerin atölye çalışmalarına ve akademik başarılarının daha yüksek düzeyde olmasına, aynı zamanda da uygulanan yöntemle kalıcı olmasına önemli katkı sağladığı saptanmıştı. Öntest ve kalıcılık testi sonrasında deney grubunun oluşturduğu uygulamalara bakıldığında, kompozisyonlarda özgünlük ve hayal gücünü kullanma, renk kullanımı, biçim özgünlüğü, çalışmanın konuya uygunluğu, hareket ve ritim, çalışmanın tamamlanması açııından, deney grubunun başarısının önemli ölçüde arttığı görülmüş, sanat yapıtlarından alıntılama yöntemiyle oluşturulan sontest çalışmalarından sonra konunun faydalı ve kalııı olduğu da, kalıcılık testiyle ortaya koyulmuştur.

\begin{tabular}{|c|c|c|c|c|c|c|}
\hline Grup & Uygulama & $\begin{array}{c}\text { Gözlem } \\
\text { Sayısı }\end{array}$ & Ortalama & $\begin{array}{l}\text { Standart } \\
\text { Sapma }\end{array}$ & t-testi & $\begin{array}{c}\text { p-değeri } \\
\text { (Anlamlılık) }\end{array}$ \\
\hline \multirow{3}{*}{ Kontrol } & Ōntest & \multirow{2}{*}{15} & 23,283 & 1,7365 & \multirow{2}{*}{$-2,853$} & \multirow{2}{*}{, 008} \\
\hline & Sontest & & 25,070 & 1,6937 & & \\
\hline & $\begin{array}{l}\text { Ōntest } \\
\text { Kalıcılık testi }\end{array}$ & 15 & $\begin{array}{l}23,283 \\
27,323\end{array}$ & $\begin{array}{l}1,7365 \\
1,2657\end{array}$ & $-7,281$ &, 000 \\
\hline
\end{tabular}

Tablo 6: Kontrol Grubu Öntest - Sontest ve Öntest- Kalıcılık Testi Başarı Puanları, t-testi Analiz Sonuçları

6- Sanat yapıtlarından alıntılamanın Resim Anasanat atölye öğrencilerinin çalışmalarına etkisine yönelik uygulama sonrasında kontrol grubunun öntest-sontest puanları arasında anlamlı bir farklılık olup olmadığına yönelik bulgular.

Tablo 6'da görüldüğü üzere kontrol grubu ön test ve son test 
puanlama değeri sırasıyla 23,28 ve 25,07 olup, öntest - sontest arasındaki farka ilişkin t-değeri -2,853 olarak hesaplanmıştır. Elde edilen değere göre kontrol grubu ön test ve son test puanları arasında istatistiksel olarak anlamlı bir fark vardır [ $t(28)=-2,853 p \leq 0,05$ ]. Fakat bu farklılık aynı konu üzerinde yapılan uygulamaların tekrarından dolayı olan bir gelişmedir. Kontrol grubu öğrencilerinin uygulamalarında, kompozisyonlarda özgünlük ve hayal gücünü kullanma, renk kullanımı, biçim özgünlüğü, çalışmanın konuya uygunluğu, hareket ve ritim, çalışmanın tamamlanması açısından farklı ve özgün işler ortaya koyamadıkları görülmüştür. Kontrol grubu açısından yapılan çalışmalara bakıldığında aynı konular üzerinde tekrar tekrar çalışmanın kompozisyonlara teknik anlamda azda olsa katkı sağladığı söylenebilir.

7- Sanat yapıtlarından alıntılamanın Resim Anasanat atölye öğrencilerinin çalışmalarına etkisine yönelik uygulama sonrasında kontrol grubunun öntest-kalıcılık testi puanları arasında anlamlı bir farklılık olup olmadığına yönelik bulgular.

Yine kontrol grubu öntest ve kalıcılık testi puanlama değeri sırasıyla 23,28 ve 27,32 olup, aradaki farka ilişkin t-değeri -7,281 olarak hesaplanmıştır. Elde edilen değere göre kontrol grubu öntest ve kalıcılık testi puanları arasında istatistiksel olarak anlamlı bir fark vardır [ $\mathrm{t}(28)=$ $-7,281 p \leq 0,05$ ]. (Bkz. Tablo 6). Fakat bu sonuç, dersin işleyişindeki normal sürecin sonucuna bağlı bir gelişimdir. Başka bir anlatımla; uygulama aşamasında kontrol grubu öğrencilerinde sürece bağlı olarak ve öğrencinin çalışma düzeyine göre bu gelişim normaldir. Araştırma sonucunda elde edilen bulguların bu şekilde sonuç vermesi beklenen ve istenilen bir durumdur. Araştırma konusuyla ilgili herhangi bir eğitim ve bilgi aktarımının yapılmadığı kontrol grubu ile araştırma konusuyla ilgili gerekli eğitim ve bilgi aktarımının yapıldığı deney grubu arasında anlamlı bir farklılığın çıkmasıyla sanat yapıtlarından alıntılama konusunun deney grubu lehine önemli ve olumlu etkilerinin olduğu görülmüştür. Aşağıda

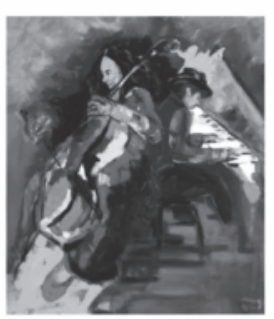

Ön Test

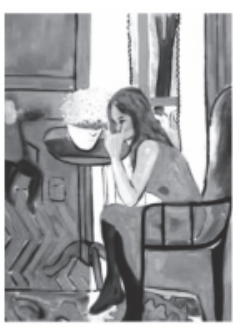

Son Test

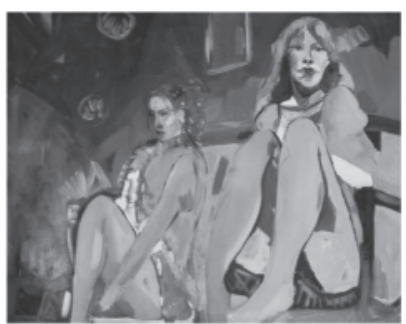

Kalıcılık Testi

Resim 5: Deney grubu öğrenci çalışması, Figürlü kompozisyon, 2013,tuvale yağlı boya 


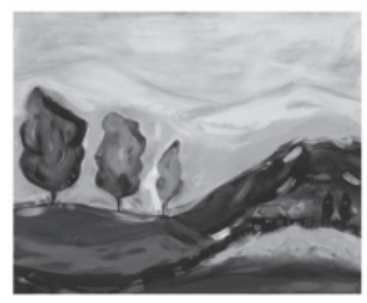

Ön Test

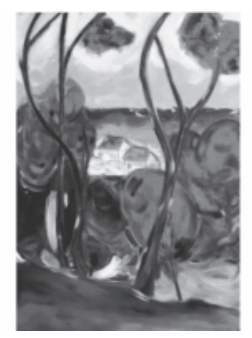

Son Test

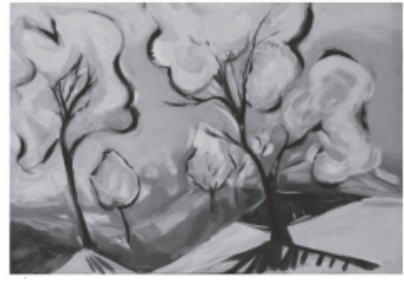

Kalıcilık Testi

Resim 6: Deney grubu öğrenci çalışması, Peyzaj, 2013, tuvale yağlı boya

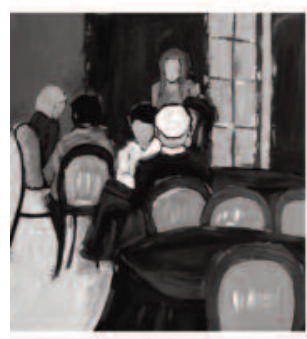

Ön Test

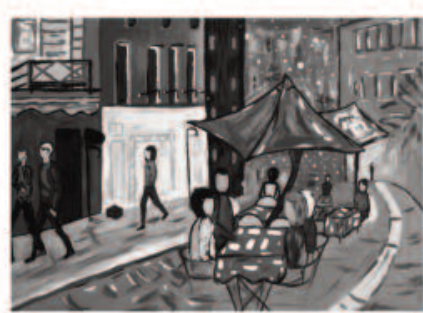

Son Test

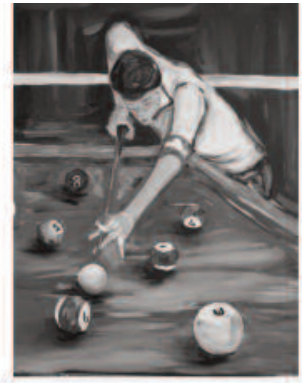

Kalıclık Testi

Resim 7: Deney grubu öğrenci çalışması, Figürlü kompozisyon, 2013, tuvale yağlı boya

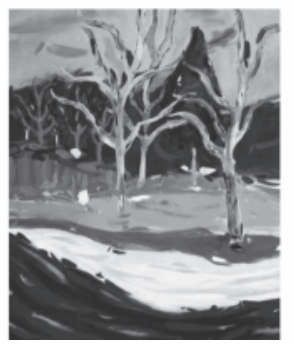

Ön Test

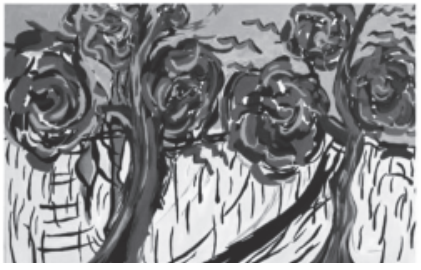

Son Test

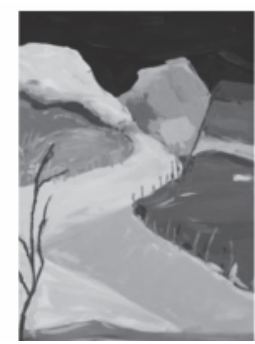

Kalıcılık Testi

Resim 8: Deney grubu öğrenci çalışması, Peyzaj, 2013, tuvale yağlı boya 


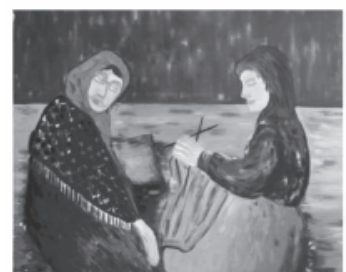

Ön Test

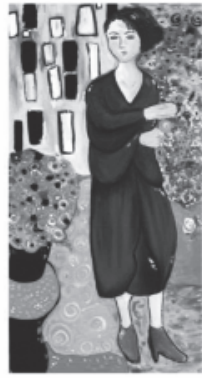

Son Test

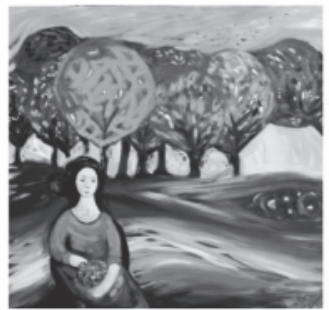

Kalıcilık Testi

Resim 9: Deney grubu öğrenci çalışması, Figürlü kompozisyon, 2013, tuvale yağlı boya

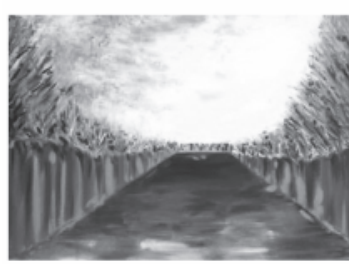

Ön Test

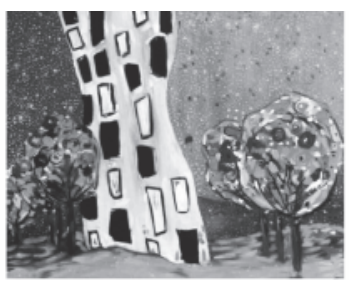

Son Test

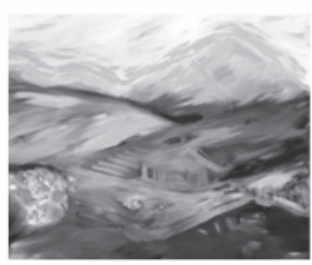

Kalıcilık Testi

Resim 10: Deney grubu öğrenci çalışması, Peyzaj, 2013, tuvale yağlı boya

deney grubu öğrencilerinin çeşitli sanatçllardan (Bkz.Res:5-6-7-8-9-10) ( Matisse, Van gogh, Klimt) alıntılama yöntemiyle, sırasıyla öntest, sontest ve kalıcılık testi kapsamında oluşturdukları peyzaj ve figürlü kompozisyonlardan örneklere yer verilmiştir.

\section{Sonuç ve Öneriler}

"Sanat Yapıtlarından Alıntılamanın Resim Anasanat Atölye Öğrencilerinin Çalışmalarına Etkisi" adlı bu çalışmada aşağıdaki sonuçlara ulaşılmıştır.

Uygulamalar sonucunda deney ve kontrol grubunun öntest t-testi analiz sonuçlarına göre başarı puanları arasında istatistiksel olarak anlamlı bir fark bulunmamaktadır. Deney ve kontrol grubunun araştırma başlangıcında denk olduğu sonucuna varılmıştır.

Sontest açısından ise deney grubu ve kontrol grubu arasındaki fark istatistiksel olarak anlamlıdır. Bu sonuca göre sontest açısından deney grubu öğrencilerinin ortalama başarısı kontrol grubu öğrencilerine göre daha yüksek olup bu fark istatistiksel olarak da anlamlıdır. 4 hafta süren uygulamanın ardından, sanat yapıtlarından alıntılamanın Resim 
Anasanat atölye çalışmalarına etkisi konulu araştırmada öğrencilere uygulanan sontest puanları arasında deney grubu öğrencileri lehine anlamlı bir fark görülmüştür. Kalıcılık testi açısından sonuçlara baktığımızda, istatistiksel olarak deney grubu ortalama puanının kontrol grubundan daha yüksek olduğu sonucuna ulaşılmıştır. Başka bir anlatımla; Sanat yapıtlarından alıntılama yöntemini kullanarak yeni çalışmalar yapan deney grubuna bu yöntemin etkileri olumlu olmuş ve deney grubu öğrencileri bu olumlu etkileri bir sonraki çalışmalarına taşıyabilmişlerdir. Kontrol grubu öğrencileri ise aynı konunun tekrar çalışılması sonucu bir ivme kazanabilmiştir.

Deney grubu öntest ve sontest puanları arasında istatistiksel olarak anlamlı bir fark vardır. Uygulama sonrasında deney grubu öğrencilerinin başarıları anlamlı bir şekilde artmıştır. Deney grubu öğrencilerinin sontest başarı puanlarındaki anlamlı artışın, sanat yapıtlarından alıntılamanın Resim Anasanat atölye öğrencilerinin çalışmalarına etkisine yönelik uygulamanın öğrencilerin atölye çalışmalarına olumlu katkılar sağladığını göstermektedir.

Deney grubu öğrencilerinin öntest ve kalıcılık testi puanları arasında istatistiksel olarak anlamlı bir fark vardır. Deney grubu öğrencilerinin kalıcılık testi sonrası başarı puanlarındaki anlamlı artış, sanat yapıtlarından alıntılamanın Resim Anasanat atölye öğrencilerinin çalısmalarına etkisine yönelik uygulamanın, öğrencilerin atölye çalışmalarına ve akademik başarılarının daha yüksek düzeyde olmasına olumlu etki sağlamıştır. Aynı zamanda uygulanan yöntemin ortaya çıkan çalışmalar doğrultusunda kalıcı olduğu da tespit edilmiştir.

Kontrol grubu öntest ve sontest arasındaki istatistiksel sonuçlara bakıldığında anlamlı bir fark görülmektedir. Fakat kontrol grubu öğrencilerindeki bu gelişme, aynı konunun tekrar çalışımasından kaynaklanan bir sonuçtur. Yine kontrol grubu öntest ve kalıclık testi arasında istatistiksel olarak anlamlı bir fark vardır fakat bu sonuç öğrencilerin dersin işleyişindeki normal sürecin sonucuna bağlı bir gelişimdir. Uygulama aşamasında her öğrencide bu sürece, öğrencinin çalışma düzeyine göre ve aynı konunun tekrar çalışılmasına bağı olarak görülen gelişim normaldir.

$\mathrm{Bu}$ sonuçlar doğrultusunda araştırma konusunun deney grubu öğrencileri için çok faydalı olduğu saptanmıştır. Ayrıca sanat yapıtlarından alıntılama yönteminin, uygulamanın başlangııından sonuna kadar belli bir disiplin içerisinde çalışan deney grubu öğrencileri için ilerdeki akademik çalışmalarında da verimlilikleri üzerinde olumlu etkiler sağlayacağı düşünülmektedir. 
Bugün geniş bir perspektiften bakıldığında sanat, sadece kendine özgü araçlarla gerçekleştirilen bir iş olmanın ötesinde, farklı disiplinlerden beslenen çoğul bir anlam arayışına dönüşmüş durumdadır. "Görsel sanatlar (resim, üç boyutlu yapıtlar, fotoğraf, video, grafik, sanal ortam imgeleri), yazın, drama, dans, müzik, film gibi alanlarla kaçınılmaz bir ilgi içine girdiği gibi, siyaset ve ekonomi bilimleri, toplumbilim ve felsefe vb. ile de ilişkilenme eğilimi içindedir" (Madra, 2002: 16). Böylece farklı disiplinlerle ilişki kurarak beslenen görsel sanatların yeni bakış açılarıyla sanata ve sanat eğitimine kazanımları olumlu olacak, sonucunda nitelikli sanat olayları ve ürünleri ortaya çıkacaktır.

Deney grubu öğrencilerinin kompozisyon ve yaratıcılıklarını geliştirerek farklı deneyimler kazanmalarını sağlayan bu araştırma sonucunda çalışmalarında, renk, kompozisyon özellikleri ve çeşitliliği, kendi eğilimlerine uygun görsel bir dil oluşturma yeterliliği ve kendine uygun üslup geliştirme açısından, konu bulma, üretebilme açısından, sanat yapıtının; oluşum sürecinde gerek duyulan kavramlar üstüne akıl yürütebilme ve yapıta dönüşüm sürecine katkısı bakımından, nesnenin sanat nesnesi olma durumu irdelemesi ve idrak etmesi bakımından, temel resim kuram ve kavramları, bir resmi dönem, teknik ve içerik bakımından analiz edebilecek görsel ve kültürel bilgi ve becerileri kazanabilmesi açısından, bir eseri analiz ederek eleştirel anlamda net sorular sorabilme ve sanatın biçimsel, teknik ve anlatımsal sorunlarına rahat çözüm sağlaması bakımından, resmin özgün bir ifade aracı olarak algılanması ve farklı teknik ve malzemeleri deneyip, eserleriyle örnekleyebilmek açısından etkisinin olumlu olduğu görülmüştür. Kontrol gurubu öğrencilerinin çalışmalarında ise sadece aynı konular üzerinde tekrar tekrar çalışmanın verdiği bir gelişme görülmüştür.

Bu sonuç, bu tür uygulamalı çalışmalarda öğrencilerin araştırmaları, bilgi toplamaları, sanatçı ve eser tanımaları, bu bilgilerin yaratıcılıkları için itici güç olduğunu anlamaları bakımından önemlidir. Ayrıca kompozisyon üretmede sıkıntı yaşayan Resim Anasanat öğrencilerine kompozisyon kurgulamada alternatif çözümler üretebilme imkânı sağlamıştır. Bu çalışma ile deney grubu öğrencileri, uygulamanın başlangıcından sonuna kadar belli bir disiplin içerisinde hareket etmeyi, sistemli, istekli ve zevkli çalışmanın verimliliği ne kadar artırdığını ortaya çıkardıkları ürünlerle kanıtlamışlardır.

Bu çalışma birçok Güzel Sanatlar Fakültesinde Resim Anasanat atölye derslerinde farklılıkların ve benzerliklerin görüntülenmesi açısından daha geniş kapsamlı yapılabilir.

Analiz, yorumlama ve uygulamaya dayalı bu tür çalışmalar öğrenci 
için yaratıcılıklarla dolu bir yaşam biçiminin başlangııı olabilir, ya da çıkış noktası olan bir yapıt, yaratıcılığının kapılarını aralayabilir. Sanat yapıtlarından alıntılama yöntemi, sanat eğitimi alan gençlerin sanatsal kavram ve becerileri öğrenmeleri, farklı disiplinlere ait bilgileri birbirine bağlamada farklı sanat eserleri ve sanatçıları kullanmaları, sanat yolu ile yaşantılarına yön vermeleri için önemli bir araç olabilir. 


\section{Kaynakça}

Aktulum, K. (2011a). Frankofoni. Ortak kitap. No: 23. Ankara: Bizim Büro Basımevi.

Aktulum, K. (2011b). Metinleraraslık//Göstergelerarasılık. Ankara: Kanguru Yay.

Bendixen, P. (2010). Managingart: An Introduction Into Principles and Conceptions. Berlin: LIT Verlag.

Berger, J. (1990). Görme Biçimleri. (Çev. Y. Salman) İstanbul: Metis Yayınları.

Büyükdüvenci, S. (2006). Sanat ve Değer. Felsefe ve Sosyal Bilimler Dergisi, (2). 47-50.

Büyüköztürk, Ş. (2001). Deneysel Desenler. Ankara: Pegem A yayıncilı.

Coıgnard, J. (1995). Ustaların Ardından Yaratmak. (Çev. G. Özturanlı) Türkiye'de Sanat (Plastik sanatlar dergisi), (17), 30-33.

Eczacıbaşı Sanat Ansiklopedisi, (1997). Cilt:3, i̇stanbul: Yem Yay.

Ekiz, D. (2003). Eğitimde Araştırma Yöntem ve Metodlarına Giriş (Nitel, nicel ve eleştirel kuram metodolojileri). Ankara: Anı Yayıncılık

Emre, i. (2006). Postmodernizm ve Edebiyat. Ankara: Anı Yayınları.

Erinç, M. S. (2009). Resmin Eleştirisi Üzerine. Ankara: Ütopya Yayınevi.

Erinç, M. S. (2004). Sanatın Boyutları. Ankara: Ütopya Yayınevi.

Erinç, M. S. (1993). Sanata Giriş ve Estetik. Fikri Cantürk (Editör), Sanata Giriş. Eskişehir. Anadolu Üniversitesi Açık Öğretim Fakültesi Yayınları, s.1-9.

Fischer, E. (2012). Sanatın Gerekliliği. İstanbul: Sözcükler Yayınları.

Gombrich, E. (2007). Sanatın Öyküsü. İstanbul: Remzi Kitabevi.

Karasar, N. (2005). Bilimsel Araştırma Yöntemi. Ankara: Nobel Yayın Dağıtım.

Lenoir, B. (2004). Sanat Yapıtı. (Çev. A. Derman) İstanbul: Yapı Kredi Yay.

Madra, B. (24 Haziran 2002). Yenilenemeyen Okullar. Radikal Gazetesi, 16.

Ötgün, C. (2008). Sanat Yapıtına Yaklaşım Biçimleri. Gazi Üniversitesi. G.S.F. Sanat ve Tasarım Dergisi, (2), 159-178.

Punch, K.F. (2005). Sosyal Araştırmalara Giriş. Nicel ve Nitel 
yaklaşımlar. (Çev. D.Bayrak, H. B. Arslan-Z.Akyüz ) Ankara: Siyasal Kitabevi.

Tolstoy, L. N. (1996). Sanat Nedir? (Çev. B. Duran) İstanbul: Şule Yay.

Yılmaz, M. (2010). Sanat Eğitiminde Kopya ve Taklit. Kazım Artut (Editör), Güzel Sanatlar Eğitiminde Özel Öğretim Yöntemleri. Ankara. Anı yayıncılık, s.193-298. 